\title{
"Em busca de um lugar no mundo": movimentos sociais e política na cidade de São Paulo nas décadas de 1940 e 50
}

\section{"In search of a place in the world": social movements and politics in the city of São Paulo in the 40's and 50'}

Adriano Luiz Duarte

O fim da Segunda Guerra inaugurou no Brasil um período de intensos debates públicos sobre as condições de vida dos trabalhadores urbanos, os serviços públicos, os equipamentos urbanos e as inúmeras expectativas sentidas como corolário dos sacrifícios realizados durante a guerra. Por quase uma década, o país vivera sob uma ditadura na qual suas demandas eram silenciadas, num complexo xadrez de violência, adesão e cooptação. A nova configuração política, com a chamada "redemocratização", redimensionou o cenário das demandas 
populares. $\mathrm{O}$ intenso clima de disputas eleitorais e o crescimento das reivindicações populares ampliaram e deslocaram os debates sobre as candentes questões urbanas do parlamento e dos partidos políticos para os sindicatos e as associações de bairros. Assim, nesses anos, estabeleceu-se uma dinâmica muito estreita entre o associativismo popular nos bairros periféricos, e as "lutas por direitos" no movimento operário, seja através dos sindicatos, seja através das comissões de fábrica. Essa dinâmica ficava ainda mais evidente durante as greves e no movimento contra a carestia.

$\mathrm{O}$ associativismo de bairro teve duas expressões fundamentais, os Comitês Democráticos e Populares (CDPs) e as Sociedades de Amigos de Bairro (SABs), as quais, sob as mais variadas influências partidárias, de um lado se assumiram como vetores das demandas populares por serviços e equipamentos urbanos e, de outro, se investiram do direito de expressá-las. Do ponto de vista das classes populares, essas organizações tornaram evidente que a idéia de democracia, ou de redemocratização, estava diretamente vinculada a moradia, transporte, trabalho, saneamento, escola, postos de saúde, lazer, liberdade de organização, baixo custo de vida etc., ou seja, àquilo que se poderia emblematicamente chamar de "direito à cidade". Desse modo, a agenda política dessas organizações colocava em discussão não apenas os termos do "direito à cidade", como também a pergunta: afinal quem falaria em nome dos trabalhadores e dos moradores dos bairros de periferia? É do funcionamento dessas associações na cidade de São Paulo que se tratará a seguir.

\section{Os Comitês Democráticos e Populares}

Em abril de 1945, o presidente Vargas assinou o decreto de anistia aos crimes políticos cometidos a partir 16 de julho de 1934. Um mês depois, realizou-se no Rio de Janeiro o primeiro grande comício legal do Partido Comunista Brasileiro (PCB). No discurso do seu secretário-geral, Luís Carlos Prestes, foi apresentado um diagnóstico das dificuldades enfrentadas pela população, e esboçada a linha de ação dos comunistas. Seu objetivo imediato era aproximar o partido da situação real e concreta da população. Sugeriu-se, para isso, a criação de comitês por local de trabalho e por bairro, os quais dariam forma à aliança de todas as forças sociais, correntes políticas e agrupamentos ideológicos, constituindo uma grande união nacional (Vinhas, 1982). O objetivo desses comitês era criar um vínculo do partido, nos bairros e nos locais de trabalho, com os potenciais eleitores. Nada faz supor que os CDPs tenham sido pensados como estratégia organizativa de longo prazo; sua finalidade parece ter sido somente a de fornecer um conhecimento abrangente das condições enfrentadas pela população e, 
a partir daí, permitir a elaboração de uma plataforma eleitoral, centrada na especificidade das condições de vida das classes populares.

O funcionamento dos CDPs variava de bairro para bairro, assim como suas estratégias foram se alterando ao longo do tempo. De modo geral, suas ações abrangiam a promoção e o desenvolvimento político-cultural dos bairros populares, o estímulo a campanhas de reivindicação de postos de saúde, bibliotecas públicas, farmácias populares, cursos de alfabetização, e o combate ao açambarcamento, ao câmbio negro e à burla do tabelamento de gêneros de primeira necessidade. Além disso, promoviam o debate dos programas dos partidos políticos, a discussão sobre as candidaturas aos legislativos municipal, estadual e federal, o intercâmbio com as demais organizações locais e o debate e esclarecimento sobre os problemas econômicos e sociais do Brasil.

Embora a questão eleitoral fosse o motor inicial da sua organização, as condições dos bairros populares emergiam como sua temática central, tanto que os CDPs de bairro foram mais numerosos e ativos que os organizados por local de trabalho. Portanto, tudo indica que a expansão dos CDPs esteve diretamente ligada à sua capacidade de expressar os anseios e as reivindicações dos moradores dos bairros populares, ao mesmo tempo que lhes dava uma maior visibilidade.

Um bom exemplo da atuação dos CDPs foi o do bairro paulista da Casa Verde. O principal acesso ao bairro era uma estreita e antiga ponte sobre o Tietêpela qual só transitava um veículo de cada vez -, não havia rede de esgoto nem água encanada, apenas poços cavados nos quintais, e também faltavam transportes coletivos, pois os bondes eram insuficientes para servir à totalidade da população de cerca de 20 mil moradores. Diante dessas mazelas, o CDP da Casa Verde, depois de seguidas assembléias, enumerou as exigências mais prementes dos moradores: a volta do bonde $\mathrm{n}^{\circ} 41$; posto médico gratuito, com creche e lactário; curso de alfabetização noturno para adultos; rede de água e esgoto; ajardinamento e iluminação da "praça Centenário"; conservação e apedregulhamento das principais ruas que ligavam a Casa Verde aos bairros adjacentes; ligação, por intermédio de linhas de ônibus, com os bairros vizinhos, e iluminação de todas as principais ruas do bairro (Hoje, 30/10/1945: 4) Os moradores redigiram um abaixo-assinado e encaminharam cópias à Prefeitura, ao Serviço de Águas e Esgotos, à Light e ao jornal Hoje. Essa mobilização resultou na criação de um curso de alfabetização de adultos na própria sede do comitê, que, no início de 1946, contava com 50 alunos.

Outro exemplo de mobilização foi a caravana de moradores do Ipiranga que se dirigiu à sede do jornal Hoje em março de 1946. Inicialmente, os moradores reclamaram da condução e propuseram que a Light colocasse reboques nos bondes, o que, em parte, desafogaria os coletivos lotados. Cobraram o estabeleci- 
mento de assistência médica e dentária no bairro, e a criação de creches nas inúmeras fábricas. Criticaram as cotas de 100 gramas de racionamento do pão, pois, afinal, com essa quantidade "não dará nem para encher as covas dos dentes" (Hoje, 17/6/1946: 9).

O jornal Hoje, órgão oficial do PCB na cidade de São Paulo, era a face mais evidente e pública da atuação e das ambigüidades do partido. Há, evidentemente, um aspecto autopromocional e positivador na sua divulgação das ações dos CDPs que, possivelmente, foram descritos com maior força, pujança e coerência do que tiveram na realidade. É certo que o espaço aberto pelo jornal Hoje, denunciando as mazelas dos bairros, era também uma forma de atrair simpatias para o PCB. Nesse sentido, os tópicos levantados pelas caravanas eram minuciosamente estudados e preparados, tanto como denúncia quanto como efeito de propaganda. ${ }^{1}$ Por isso, o jornal deve ser lido com cuidado.

De toda forma, e é isso que importa, o Hoje foi o primeiro jornal a abrir espaço para a discussão das condições de vida nos bairros da periferia de uma grande cidade no pós-guerra. Depois dele, outros jornais da grande imprensa fizeram o mesmo. O Correio Paulistano e o Diário de São Paulo, por exemplo, aproveitando a publicidade do tema, também criaram colunas diárias sobre as condições dos bairros operários.

Os temas que norteavam a organização dos CDPs traziam à tona uma longa experiência de carências que chamava a atenção para as deficiências específicas dos subúrbios da cidade. Isso não significava que as preocupações de política geral estivessem em segundo plano, mas, certamente, eram os temas do cotidiano que mobilizavam os moradores. Por isso, os CDPs parecem ter oscilado entre uma atuação política mais geral, de acordo com a inspiração do PCB, e a denúncia do verdadeiro estado de calamidade em que se encontravam os bairros periféricos da cidade. Essa dupla orientação não escapou às lideranças do partido.

Nem sempre temos compreendido a natureza desses organismos, e, por isso mesmo, não são poucos os que agrupam apenas membros e simpatizantes do partido, subestimando a mobilização dos moradores locais [...]. Os que levantam reivindicações gerais e debatem alta política têm pouco apoio popular. Mas aqueles que lutam pelas coisas mínimas, sentidas por todos, crescem rapidamente. (Pomar, 1945)

O vertiginoso crescimento dos CDPs nos bairros operários chamou a atenção dos órgãos de segurança pública, que desde o início monitoraram suas 
ações. E o modo como foram percebidos é revelador dos dilemas enfrentados pelas organizações populares no pós-guerra: "criados em quase todos os bairros da capital e mesmo do interior do estado, nada mais são do que entidades que mascaradas de democráticas e beneficentes têm a precípua finalidade de atrair maior número de simpatizantes para o credo moscovita". O relatório do agente da Delegacia de Ordem Política e Social (Dops) prosseguia sugerindo que os CDPs representavam um "fenômeno novo e interessante" que revelava "a inteligência do modus operandi" dos comunistas. A novidade estava em promover reuniões "de interesse geral e de fins beneficentes ao bairro e ao povo". Por isso, os CDPs atraíam "todas as classes sociais, dominando, porém, a classe proletária, que ia se deixando empolgar por uma pseudo-assistência jurídica e social, reivindicações proletárias, conselhos paternais e outros serviços de menor importância, inclusive promessas de uma vida muito mais suave e feliz". O relatório terminava com a constatação de que muitos "burgueses progressistas" foram atraídos aos CDPs, não apenas fornecendo ajuda financeira, mas com uma presença ativa, "convencidos de que praticavam atos de humanidade, quando na verdade estavam trabalhando para a Rússia Soviética" (Arquivos do Dops, Prontuário n ${ }^{\circ}$ 2.431, vol. 10). Nesse sentido, um dos perigos dos CDPs estava no fato de eles se abrirem a uma composição social heterogênea que dificultaria a clara identificação daqueles "tradicionalmente" percebidos como "classes perigosas". Parece claro que os comitês desnorteavam as percepções convencionais da política.

Ao longo de 1946, como sugeriu Sílvio Alem - por conta das seguidas tentativas de enquadramento feitas pela direção do PCB -, os CDPs foram se transformando em organismos parapartidários. Primeiro, criou-se a Comissão Organizadora de Democratização e Reivindicações Populares, cujo objetivo era coordenar e disciplinar a ação e o funcionamento dos CDPs. Em fins de 1945, já se tentara organizar um "congresso nacional” dos CDPs, com o claro propósito de coordenar nacionalmente suas ações. Entretanto, a idéia do congresso não prosperou (Alem, 1981). O objetivo do PCB era claro: dirigir as ações dos CDPs para os temas "corretos", talvez porque, no dia-a-dia, sua prática deslizasse para os problemas cotidianos dos bairros, deixando de lado os temas de interesse do partido. Por isso, foram freqüentes, ao longo de 1946 e 1947, as matérias no Hoje enfatizando o papel político-partidário dos CDPs, numa clara tentativa de disciplinar suas ações. Pelo que se percebe, nessa longa série de atritos, nem sempre os CDPs atuaram como esperava e planejava a direção do PCB. Nesse sentido, os CDPs parecem ter expressado a própria ambigüidade do Partido Comunista.

É conveniente tomar a metáfora da existência de dois PCs. De um lado, o partido da "ordem e da tranqüilidade", expressão das suas direções e do seu projeto de inserção no cenário político partidário. De outro, o "partido das ruas, das 
praças, das festas populares, dos bairros operários, das fábricas e que, enquanto organização partidária, foi praticamente o único a exercer forte sedução sobre a classe trabalhadora e a juventude" (Costa, 1995:180). Nas instâncias partidárias, de modo geral, os CDPs foram tomados, principalmente, como instrumentos de mobilização popular e não como movimentos sociais capazes de estabelecer práticas inovadoras que pudessem enraizar experiências democráticas. Paradoxalmente, a curta duração dos CDPs se deveu à própria direção do Partido Comunista.

Entretanto, o sucesso eleitoral dos candidatos do PCB, especialmente nas eleições de 1947 para a Câmara Municipal de São Paulo, esteve estreitamente conectado à sua vinculação com os CDPs e, principalmente, à sua inserção nas discussões sobre as condições dos bairros operários. Por exemplo, em novembro de 1947, um repórter do jornal Hoje descreveu um comício do candidato comunista Luiz João no bairro da Mooca:

Observou-se a necessidade da prolongação da linha de bondes Taquari, e a volta à circulação do ônibus $\mathrm{n}^{\circ} 27$, bem como o prolongamento do itinerário do ônibus $\mathrm{n}^{\circ} 16$. O Alto da Mooca pede calçamento para suas ruas principais, todas elas destituídas de sarjetas e passeios, transformando-se em verdadeiros lamaçais em dia de chuva. Necessitamos também de uma agência dos correios e telégrafos e de um posto policial. Sem transporte suficiente, sem agência de correio e telégrafo e sem policiamento eficaz o Alto da Mooca com sua grande população obreira assemelha-se a uma dessas abandonadas vilas do interior. As crianças do Alto da Mooca pedem um parque infantil. O povo necessita de hospitais, as gestantes pobres de maternidade e postos de assistência médica, um mercado popular a fim de eliminar a especulação. (Hoje, 8/11/1947: 2)

O pedreiro Luiz João foi eleito vereador porque expressou de forma clara sua ligação com os problemas concretos enfrentados pela população da Mooca. $^{2}$ O PCB do bairro da Mooca, naquela primeira eleição em 13 anos para a Câmara Municipal, apresentou quatro candidatos: além de Luiz João, Afonso Liguori, Faustina Bonimani e Antônio Donoso Vidal. Dos quatro, apenas Faustina Bonimani - que fez sua campanha centrada nos trabalhadores da indústria têxtil e não nos CDPs - não foi eleita. O vizinho bairro do Belém elegeu outros dois vereadores ligados aos CDPs: Armando Pastrelli e Benedito Jofre, além de Orlando Piazotto, eleito deputado estadual. 
Muito já se argumentou que o rápido crescimento do PCB no pós-guerra pode ser atribuído ao prestígio gozado pela URSS, à consideração pessoal de Prestes e dos comunistas presos, que teria crescido na proporção direta do aumento das simpatias pelas vitórias soviéticas após a invasão alemã, e ainda à ausência de uma organização de esquerda que pudesse concorrer com os comunistas (Alem, 1981). O metalúrgico Alfredo Castanha, que nunca foi membro do PCB, embora tivesse sido um fiel eleitor do partido e membro do CDP do bairro da Mooca, acrescentou outra razão para o sucesso do partido no pós-guerra: "Porque a luta do PCB era em favor do trabalhador. Tudo que era bom para o trabalhador era bom pra ele [o partido]" (Castanha, 1999).

Foi desse ponto de vista que o também metalúrgico e imigrante lituano Julius Meksenas explicou a popularidade do PCB no pós-guerra: "E a atuação desses Centros Democráticos é que possibilitou o Partido de ter essa votação..." (Meksenas, 1999) Dessa perspectiva, o sucesso do PCB no pós-guerra se devia também, e talvez principalmente, à sua inserção capilar nos bairros de subúrbio, através dos CDPs. Em outubro de 1945, já existiam 31 CDPs em funcionamento na cidade de São Paulo, 28 em Santos e muitos outros em processo de organização. Segundo o jornalista Noé Gertel, o CDP [foi] "uma forma de organização da massa, quer dizer, o partido como partido era muito difícil se ligar às massas. Então se criou o CDP que era uma frente. Uma forma de unir os bairros, de unir o povo em torno das reivindicações específicas do bairro, mas também de politizar..." (Gertel, 1999) Um panfleto do CDP dos bairros Jardim Paulista, Itaim e Vila Nova Conceição, arquivado no Dops, nos dá uma idéia dos meios e da amplitude de sua ação: "Os amigos do Jardim Paulista e bairros adjacentes convocam uma reunião para tratar democraticamente de assuntos e reivindicações de seus bairros e de um modo geral dos interesses populares, tais como: água, luz, esgoto, calçamento, higiene, escolas para crianças e alfabetização de adultos, centro de saúde, etc."3

O crescimento rápido e desordenado da cidade e o descaso do poder público se somavam para produzir a deterioração das condições de vida urbana. Para enfrentá-los, os CDPs optaram por tornar públicas as condições dos bairros e, mais que isso, assumiram realizar as tarefas que estivessem ao seu alcance. Exemplo disso aconteceu na Vila Matilde. Situado ao lado da estrada de ferro Central do Brasil, o bairro tinha uma população estimada em mais de $18 \mathrm{mil} \mathrm{ha-}$ bitantes. Os moradores, na maioria trabalhadores da indústria e do comércio, conviviam com ruas esburacadas, iluminação deficiente, falta de transporte e de escola - anualmente, cerca de $50 \%$ das crianças do bairro ficavam sem matrícula escolar. Por iniciativa do CDP, os moradores resolveram dar início à construção de uma escada de acesso à estação ferroviária. Na primeira parte, projetaram 26 
degraus, com um patamar de oito metros; na segunda parte, 24 degraus e outro patamar. Todo o material de construção, cimento, areia, ferro, madeira etc., foi coletado na "campanha das tábuas" (Hoje, 16/3/1946: 5). A atuação do CDP não se limitou nesse caso à simples denúncia do abandono e das carências do bairro; ele foi o vetor não apenas da percepção pública dos problemas, mas também da sua solução.

A simples publicidade das carências e das dificuldades vivenciadas nos bairros periféricos transformou-se num poderoso recurso de mobilização "num mundo habituado a explorar em silêncio" (Castels, 1980). Havia dois modos básicos de dar publicidade aos problemas dos bairros: o contato dos CDPs com os jornais (o Hoje tinha uma coluna diária intitulada "A vida dos CDPs", onde se noticiavam as atividades dos grupos dispersos pela cidade) e os espalhafatosos "Comandos do Hoje", quando os jornalistas, em caravana, visitavam os bairros. $\mathrm{O}$ "comando", segundo um jornalista participante:

Era uma coisa sensacional, era um caminhão com uma faixa: Fornal Hoje; botavam duas ou três mesinhas no caminhão, com máquinas de escrever, dois ou três repórteres, e anunciávamos no Hoje: 'amanhã vamos estar no bairro tal...' E aquilo passava à noite circulando pelo bairro, avisando. No dia seguinte, na hora marcada, estava cheio de gente para subir no caminhão e falar com os repórteres. Daquilo surgiam então as principais necessidades do bairro, os principais problemas do bairro. Aí, no dia seguinte, vendia jornal naquela área brutalmente, todo mundo queria ver. (Gertel, 1999)

A presença dos "Comandos do Hoje" tornou-se um acontecimento nos bairros do subúrbio. Os repórteres desciam dos caminhões e circulavam pelas ruas entrevistando os moradores sobre os mais variados temas. Mas a senha para o início do diálogo era a pergunta: "Quais os problemas do seu bairro?” As reclamações mais freqüentes diziam respeito à ausência dos serviços urbanos básicos: iluminação nas casas e nas ruas, hospitais, creches, telefones públicos, parques infantis etc. Os repórteres dos "Comandos do Hoje" eram conduzidos, através das ruas "empoeiradas, sem calçamento e sem iluminação", por moradores que, ao mostrar o bairro, enfatizavam a falta de condução, iluminação, água, escolas, postos médicos etc. etc. etc. No bairro da Freguesia do Ó, um morador argumentou: "Tudo isso precisa ser feito com urgência, pois a vida aqui está insuportável. Além do mais, os habitantes têm direto de exigir tudo isso, pois com trabalho e impostos eles contribuem para o enriquecimento dos cofres públicos" (Hoje, 
17/9/1946: 6, grifo meu). Em Vila Independência, o repórter de um "Comando do Hoje" desceu a rua 2 de Junho, único meio de acesso ao bairro. No final da rua, deu com uma pequena ponte de madeira - construída pelos próprios moradores - e, depois de atravessá-la, encontrou o morador Manoel Hernandes, que expressou de forma lapidar o sentimento dos moradores: "Este bairro se encontra fora do mundo".

As demandas pela inclusão social e pelo "direito à cidade" apareciam estreitamente ligadas à questão da melhoria das condições gerais dos bairros periféricos. Esses eram os temas nos quais, do ponto de vista das classes populares, se resumiam a redemocratização, o progresso e o desenvolvimento. Esse conjunto de reivindicações, denúncias e mobilizações coletivas colocava em cena a busca por um "lugar no mundo", pelo direito aos benefícios da redemocratização e aos frutos do progresso. O ponto de partida era a constatação de que os bairros periféricos e seus moradores "não fazem parte da cidade" e, ao serem excluídos dos seus limites, simbólicos ou reais, eram excluídos também do mundo. "Estamos complemente afastados da civilização", foi o que disse Raimundo Guimarães, morador de Vila Prudente, ao repórter do Hoje (Hoje, 8/5/1947: 6, grifo meu)

A linguagem dos direitos era seguidamente pronunciada nos CDPs e passou a fazer parte do vocabulário corrente das classes populares. Afinal, os moradores "têm direito de exigir tudo isso". A descrição das mazelas dos bairros operários punha em xeque o modelo de cidade que se construía, e desvendava os significados da "redemocratização" do ponto de vista dos "cidadãos esquecidos no fim de mundo". Os CDPs deram visibilidade e publicidade a uma situação bastante complexa, que colocava as mais simples e imediatas demandas populares na agenda da "grande política". Nesse sentido, eles ultrapassaram, e muito, as perspectivas eleitorais imaginadas pela direção do PCB.

Num certo sentido, os CDPs adquiriram vida própria e alcançaram uma certa independência da direção do partido na disputa cotidiana pelos corações e mentes nos bairros operários. Essa intensa mobilização nos bairros periféricos não foi invenção do PCB - embora ele tenha sido o primeiro a fazê-la de forma sistemática -, e já se sugeriu que as organizações de bairro antecederam a legalidade do partido. A novidade, entretanto, foi dar voz a essas organizações por meio de um jornal diário, o Hoje, e, desse modo, conectar as associações até então dispersas, dando-lhes um eixo comum. Não surpreende, portanto, que a fórmula dos CDPs, que alcançou enorme visibilidade, tenha sido utilizada posteriormente por políticos e partidos dos mais variados matizes. O seu potencial mobilizador - ou, dito de outra forma, o seu potencial eleitoral - já fora testado. Restava, apenas, para uma utilização oportuna, a sua desvinculação do PCB e o esvaziamento do seu conteúdo político e ideológico. Esse objetivo foi alcançado com a disseminação das Sociedades de Amigos de Bairro, depois de 1947. 


\section{As Sociedades de Amigos de Bairro}

As SABs surgiram no cenário político brasileiro antes de 1945, mas cresceram vultosamente apenas depois da decretação da ilegalidade do PCB, em maio de 1947. Em muitos casos, as SABs e os CDPs trabalharam em conjunto; mais do que isso, há indícios de que houve um trânsito contínuo de membros de uma para outra organização, embora até 1947 os CDPs tivessem - pela própria existência do jornal Hoje e pela vinculação com o Partido Comunista - uma visibilidade e uma politização maiores que as das SABs.

O surgimento das $\mathrm{SABs}$, ainda em plena vigência do Estado Novo, intrigou e inquietou os órgãos da Segurança Pública. Em fevereiro de 1945, o delegado chefe do setor político do Dops incumbiu um investigador de fazer um levantamento de todas as organizações de bairro espalhadas pela cidade. Constatou-se a existência de dez "Sociedades de Amigos" funcionando apenas na capital, a grande maioria fundada entre 1942 e 1944. Segundo o investigador, "as sociedades não possuíam fins políticos ou religiosos, limitavam-se à expressão cultural e artística [dos bairros]" (Arquivos do Dops, Dossiê 20-J-0-10). A preocupação dos órgãos de segurança pública era a conexão dessas organizações com o ainda ilegal Partido Comunista. Depois de algum tempo de "trabalho", o investigador encaminhou seu relatório final com uma pequena nota: "Os elementos que compõem a diretoria da SAB do Tucuruvi e de Vila Maria pertenciam ao Partido Republicano Paulista, os da Casa Verde são pessepistas [do Partido Social Progressista, PSP]".

Ao terminar seu relatório, o investigador manifestava sua incontida surpresa "pela total ausência de membros, ou mesmo de simpatizantes, do Partido Comunista nessas entidades" (Arquivos do Dops, Dossiê 20-J-0-6.) Além dessa informação, ele acrescentou um quadro das profissões dos membros das associações. No Tucuruvi, o presidente era advogado; o vice-presidente, médico; o secretário-geral, serventuário da justiça; o primeiro-secretário, ferroviário; o segundo-secretário e o primeiro-tesoureiro foram descritos como "proprietários" (pequenos comerciantes?); o segundo-tesoureiro, dentista. O conselho consultivo era composto por quatro coronéis, um major e um médico. Na Casa Verde e em Vila Maria, de modo geral, repetiam-se as mesmas profissões encontradas no Tucuruvi: dentistas, médicos, corretores de imóveis, farmacêuticos e, em menor número, alguns operários. Essa composição pode sugerir que, enquanto os CDPs existiram, as SABs agregaram o que se poderia chamar a "classe média" dos bairros periféricos.

Entretanto, a maior dificuldade para compreender a história das SABs está no fato de que, com raras exceções, elas tiveram uma vida fragmentária e intermitente, sendo criadas e recriadas continuamente. De modo que apenas um 
estudo caso a caso pode revelar as múltiplas e variadas relações entre CDPs e SABs. Todavia, há indícios de que a cassação do registro do PCB, em maio de 1947, levou muitos dos antigos membros dos CDPs a se refugiarem nas SABs, a fim de evitar as perseguições e dar continuidade à sua ação política (os arquivos do Deops/SP sugerem que um fenômeno semelhante aconteceu na cidade principalmente depois da decretação do AI-5, em dezembro de 1968). De qualquer modo, a história dos CDPs e das SABs parece umbilicalmente ligada. O que os CDPs fizeram, sem dúvida, foi dar à organização das SABs, onde elas já existiam, um caráter mais popular e politizado. Parece razoável supor que as SABs e os CDPs tenham se influenciado mutuamente e que, com a ilegalidade do PCB, as SABs colheram os frutos da enorme visibilidade das "questões do bairro" que a existência dos CDPs havia proporcionado. ${ }^{4}$ Portanto, desde o início, as SABs (tanto quanto os CDPs) estiveram profundamente imbricadas nas teias das organizações político-partidárias. E é exatamente a partir das configurações partidárias e das disputas e dos conflitos políticos delas originados que se pode elucidar não apenas o seu surgimento, mas a sua trajetória.

A política partidária com suas múltiplas implicações, mais do que estar presente na história dessas associações de bairro, é a chave para a sua compreensão. As relações entre SABs e CDPs foram reveladoras das tessituras políticas nos bairros de periferia. Um exemplo está na criação da SAB da $4^{\mathrm{a}}$ Parada e do Belém, em julho de 1946, no momento em que o CDP do bairro estava a todo vapor. Na justificativa para a sua criação, estava a luta por calçamento, iluminação e transportes, pela criação de um hospital infantil e de uma creche, bem como pelo estabelecimento de uma cooperativa de consumo de gêneros de primeira necessidade - como se vê, os mesmos temas da agenda dos CDPs. O personagem central na criação da SAB do Belém foi o padre Arnaldo de Morais Arruda. Na ocasião, este

referiu-se ao significado da criação da $\mathrm{SAB}$, que congrega no seu seio cidadãos animados do desejo de prestar serviços à coletividade, o que servia de exemplo aos demais bairros, onde outras entidades semelhantes haverão de erguer-se, como sentinelas dos interesses do povo, sem cogitar, entretanto, de política ou questões religiosas, pois que a melhor política e a melhor maneira de servir a Deus é levar o bem-estar, o conforto e a tranqüilidade aos lares dos que trabalham. (Hoje, 23/7/1946, grifos meus.)

Aparentemente, a SAB nascia para contornar a conexão comunista do CDP local. Contudo, um ano depois, dois componentes da SAB foram eleitos 
para a Câmara Municipal: o padre Arnaldo de Morais Arruda (pelo PSP) e Armando Pastrelli (pelo PST). Dos nove membros que participaram da sua primeira diretoria, três eram também membros do CDP e foram fichados no Dops como "notórios comunistas", inclusive o vereador eleito Armando Pastrelli. ${ }^{5}$ Ao menos nesse caso, não há dúvida: a criação da $S A B$ visava ampliar o leque da composição social do CDP, atraindo uma significativa parcela da classe média do bairro e esvaziando o ativismo local de suas conotações de esquerda. Essa ampliação na composição social dos participantes foi ilustrada no ato público promovido pela $S A B$, um mês depois da sua criação, em frente à igreja de São Paulo, na rua Tobias Barreto. Do púlpito, o padre Arnaldo convocou os moradores, alegando que o momento era grave e requeria a união de todos. Afinal, "quando um náufrago está em perigo não se pergunta a quem se atira um salva-vidas se é católico, protestante, ou ateu". Por isso, não se deviam fazer perguntas sobre "religião ou política" aos membros da SAB. Ao final do seu sermão, o padre Arnaldo anunciou que a $\mathrm{SAB}$ contava com o auxílio financeiro de vários industriais do bairro, que estavam dispostos a ajudar doando um terreno para a construção de um hospital onde não seria necessário fazer filas nem "arranjar 'cartuchos' ou 'pistolões' para o atendimento".

A história das SABs (e do associativismo de bairro) está assentada numa dupla e tensa condição: negociação constante com os poderes públicos e os partidos políticos, de um lado; e um grande esforço para se constituir como expressão dos interesses dos moradores dos bairros da periferia, de outro. A independência e autonomia das organizações de bairro, nas décadas de 1940 e 50, foi constantemente atravessada pelas disputas político-partidárias e pelos interesses eleitorais locais; exatamente por isso, tais associações exprimiram uma singular maneira de se relacionar com o jogo político, num contínuo aprendizado de difíceis negociações sobre o sentido da autonomia.

Essa "negociação" foi um caminho curto para o estabelecimento de um vínculo "clientelista" das SABs com os políticos. Mas seria um equivoco supor que tais práticas surgiram de fora para dentro das experiências populares. Se não encontrasse campo fértil nas experiências populares, esse "é dando que se recebe" possivelmente não teria se tornado um sofisticado instrumento de barganha. Essa profunda imbricação entre os interesses locais e as políticas clientelísticas talvez possa ser atribuída a uma longa tradição brasileira. Como sugeriu Wanderley Guilherme dos Santos, ser pobre no Brasil é uma condição associada a uma altíssima taxa de aversão ao risco, o que implica uma opção por estratégias organizativas que evitem o conflito - no mais das vezes estratégias conservadoras e de sobrevivência -, a que o autor chamou de "custo do fracasso". As desigualdades sociais no Brasil seriam tão profundas que quaisquer ações coletivas 
implicariam um alto risco de perda do status quo e, por mais insignificante que fosse, sempre seria possível, para os pobres, piorar sua condição de vida. Sendo assim, "o voto clientelístico é o único recurso de poder das populações carentes em que o custo do fracasso é zero" (Santos, 2006:180).

Portanto, o que marcaria a diferença entre os CDPs e as SABs seria, por um lado, a maior heterogeneidade e pluralidade social na composição das SABs e, por outro, o modo de encaminhar suas reivindicações. Os CDPs, por conta de seus vínculos com o PCB, geralmente encaminhavam aos órgãos competentes do poder público municipal ou estadual abaixo-assinados e petições, acompanhados de passeatas, visitas coletivas, sempre com estardalhaço, pois as ações tinham um evidente papel pedagógico de visibilidade e mobilização popular. Para as SABs, a mobilização coletiva não era a questão mais importante, pois, pelos próprios mecanismos da lógica clientelística, era importante que as benfeitorias aparecessem como dádivas ou doações dos políticos generosos que intermediavam a negociação. Assim, com os mesmos abaixo-assinados e petições, faziam o percurso até o poder público, quase sempre por intermédio de algum vereador, deputado ou diretório partidário.

Embora as condições de trabalhador e morador não sejam intercambiáveis, cada uma delas mantendo a sua especificidade, elas se encontravam, em circunstâncias específicas, tanto nas reivindicações do mundo do trabalho quanto nas demandas urbanas dos bairros do subúrbio. Entretanto, em decorrência das dificuldades, teóricas e metodológicas, em lidar com esses complexos nexos, disseminou-se a idéia de que a categoria "morador" teria sido capaz de dissolver os comportamentos de classe e de se sobrepor à condição de trabalhador. ${ }^{6}$ Ao contrário do que se supôs, as organizações de trabalhadores e de moradores cruzaram as suas "fronteiras" e foram capazes de unificar, a partir de experiências muito sofisticadas, as reivindicações das fábricas e dos bairros, sobretudo porque elas foram percebidas como continuidade uma da outra. O Comitê Operário contra a Carestia de Vida, por exemplo, criado em novembro de 1944, foi uma das muitas organizações surgidas nesses anos capazes de conectar o movimento sindical e o associativismo de bairro, culminando na criação do Movimento Unificado dos Trabalhadores (MUT), em abril de 1945.

Em março de 1953, na notável "greve dos 300 mil", a mobilização nos bairros envolvidos com o clima da primeira eleição para a Prefeitura da capital (a última eleição direta havia sido em 1926), foi fundamental na estruturação do apoio ao movimento. No bairro da Mooca, por exemplo, na rua Javari, foi instalada a cozinha comunitária que funcionava das seis da manhã às dez da noite, $\mathrm{e}$ que teve na SAB local um apoio fundamental (Costa, 1995: 180). Em agosto, realizou-se o primeiro comício pró-congelamento de preços, no largo São José do 
Belém, promovido em conjunto pela SAB, a União dos Moradores da Mooca e vários sindicatos. No dia 2 de setembro, uma assembléia do Pacto de Unidade e Ação decidiu deflagrar uma greve de 24 horas pelo congelamento de preços e por aumento de salários. Embora contasse com o apoio dos sindicatos, o sucesso desse movimento dependeria, e muito, das organizações de bairro. Em 7 de maio de 1955, realizou-se na Mooca um comício pró-congelamento de preços; o investigador do Dops destacado para o evento relatou que estavam presentes representantes dos sindicatos dos hoteleiros, comerciários, vendedores do comércio varejista, metalúrgicos, gráficos, têxteis, assim como representantes da Federação de Mulheres e "membros da Sociedade Amigos de Bairro".

Desde o início de 1957, os agentes do Dops registravam a presença de representantes da SABs nas reuniões convocadas pelo Pacto de Unidade Intersindical. Nessas reuniões, entre outros assuntos, "se discutia o aumento do custo de vida e os problemas de abastecimento na cidade de São Paulo". Em março, realizou-se uma reunião na sede da Sociedade Amigos do Burgo Paulista, com a presença de representantes de uma dezena de SABs; um dos temas discutidos foi o apoio das organizações de bairro "ao Pacto de Unidade Intersindical ajudando no cumprimento de seu programa" (Notícias do Hoje, 9/3/1957: 4). Em outubro, durante a "greve dos 400 mil", a Federação das SABs redigiu um manifesto de apoio aos grevistas:

Considerando que as sociedades amigos de bairro, vilas e entidades congêneres são constituídas por uma maioria absoluta de trabalhadores de todas as categorias e profissões; considerando que a luta pelo barateamento do custo de vida é inerente a todo o povo sem qualquer distinção e que esta federação vem igualmente pugnando contra a carestia, por vários meios e modos [...]. Servimo-nos da presente para hipotecar nossa mais irrestrita solidariedade aos trabalhadores em greve, na expectativa de que as organizações populares de bairros e vilas possam, efetivamente, colaborar no serviço de amparo às famílias dos grevistas por meio de iniciativas e realizações adequadas, de acordo com os recursos de que possam dispor. Com os votos de uma ampla e bem merecida vitória, que será a vitória do povo contra a fome e a carestia, subscrevemo-nos. $^{8}$

A organização de manifestações como essas colocava as SABs e os sindicatos em uma estreita relação, na qual ambos se reconheciam como interlocutores legítimos no encaminhamento das demandas populares. A conexão entre movimento operário e movimento de bairro foi facilitada, também, pela con- 
fluência pontual de certas demandas, e pela dupla atuação das pessoas envolvidas com ambos.

\section{O ativismo de bairro entre Ademar e Jânio: clientelismo?}

É muito difícil compreender a trajetória das SABs sem fazer referência a duas das figuras mais emblemáticas do cenário político brasileiro naqueles anos: Ademar de Barros e Jânio Quadros. ${ }^{9}$ Em 1945, Ademar de Barros, que fora interventor nomeado por Vargas, fundou o Partido Social Progressista, cuja base eram os contatos estabelecidos no período da sua interventoria. Eleito governador em janeiro de 1947 com o decisivo apoio do PCB, Ademar utilizou-se habilmente da estrutura governamental e dos recursos públicos para transformar o PSP na mais capilar e sofisticada organização partidária do estado de São Paulo, entre as décadas de 1940 e 60.

A ilegalidade do PCB abriu o caminho para que o PSP se consolidasse em várias regiões operárias onde os comunistas haviam prevalecido na sua breve existência legal. Além disso, o PSP foi beneficiado pelas incessantes disputas internas da seção paulista do Partido Trabalhista Brasileiro (PTB) (Benevides, 1989). Desde o início de sua carreira política, Ademar de Barros foi uma figura carregada de ambigüidade, um "político tradicional" que percebeu a novidade, para o cenário político, dos novos eleitores moradores nos bairros periféricos que cresciam rapidamente. Como destacou John French, a vitória de Ademar nas eleições de 1947 "assinalou o surgimento de um novo tipo de chefe político que se dispunha a cortejar, ainda que oportunisticamente, a população urbana e operária do estado" (French, 1995). Com um discurso permeado de referências classistas e dirigido aos trabalhadores, reconhecendo-os como interlocutores legítimos, Ademar condenava as desigualdades sociais e atacava as "elites", consideradas egoístas e arrogantes, criando em torno de si uma imagem de generosidade e de fácil acesso para os trabalhadores.

Rapidamente, o PSP desenvolveu uma fantástica máquina eleitoral. Os diretórios distritais, que correspondiam a um Distrito de Paz, formavam a base do partido. Cada diretório distrital indicava o respectivo juiz de paz, o delegado de polícia e o subdelegado. Cada subdelegado escolhia os inspetores-de-quarteirão, cuja função era zelar pela "sua rua". Essa estrutura garantia, em cada distrito, uma teia de contatos e apoios que poderia ser facilmente acionada nos momentos oportunos. Os bairros podiam ser totalmente esquadrinhados. Formava-se, literalmente, uma teia de contatos e apoios capaz, não apenas de apurar reivindicações específicas de cada uma das ruas do bairro, mas, sobretudo, de se informar sobre os acontecimentos cotidianos em cada quarteirão. O fluxo de "fa- 
vores" e "benefícios" tinha, necessariamente, que passar pela máquina partidária do PSP, pois isso garantia que as demandas retornassem como votos, assegurando a hegemonia partidária. ${ }^{10}$

O coração dessa estrutura estava o no seu vínculo com os temas e as organizações de bairro e na sua capacidade de traduzi-los em apoio e votos. O sucesso dessa armação, no entanto, dependia do ganho simbólico de poder e influência que ela podia representar. A capacidade de barganha, o prestígio e a inserção dos diretórios distritais do PSP nos bairros periféricos dependiam da sua habilidade para negociar internamente com o restante do partido e conquistar, seja do poder municipal, seja do poder estadual, as demandas dos moradores. Nesse sentido, a máquina partidária local funcionava como uma instância intermediária entre essas demandas populares e o poder executivo. Na prática, essa função era extremamente frágil, porque o não-atendimento das demandas ameaçava o desmoronamento de todo o edifício partidário. A possibilidade de que as demandas populares não passassem pela estrutura do PSP, por outro lado, abria a brecha para que se pudesse prescindir do partido.

Isso se tornou cada vez mais comum com o crescimento das SABs, que passaram a negociar as demandas dos bairros operários (diretamente com os vereadores ou deputados de qualquer agremiação política) sem a necessária intermediação da máquina do PSP. Desse modo, a aparentemente imbatível estrutura do PSP podia ser ameaçada pelo crescimento das SABs. Isso explica as constantes referências dos ademaristas às $\mathrm{SABs}$ como as únicas organizações do bairro capazes de competir, efetivamente, com a máquina do PSP.

As Sociedades Amigos de Bairro foram criadas justamente para combater o PSP. [...] Ninguém conseguia fazer um partido igual ao PSP, nós éramos imbatíveis como partido. Nós aproveitamos a época do Getúlio e foi fácil a gente penetrar. Nós íamos para a rua, fazíamos comícios, fazíamos contatos, íamos na igreja, com o padre, o farmacêutico, o dono do armazém. Nós conseguimos montar uma estrutura. Depois, quem não fez, quando começava a correr, nós já estávamos na frente. (Depoimento de Armindo Rocha em 13/1/1978 em Sampaio (1982: 145))

Isso produziu duas reações: uma enorme disputa pelo controle das SABs, e uma clara oposição do PSP quando o partido não conseguia controlar o funcionamento destas. E foi exatamente nessa fissura que cresceu a figura de Jânio Quadros. Ele foi, possivelmente, o político que melhor catalisou a fricções entre o PSP e as SABs. 
Jânio iniciara sua vida pública como adversário do então governador Ademar de Barros e do PSP, notabilizando-se pelas ásperas críticas à administração da cidade e pelas denúncias de corrupção e desmandos na máquina pública. Desde a campanha para a Câmara Municipal de São Paulo, em 1947, pelo Partido Democrata Cristão (PDC), já demonstrara grande sensibilidade em relação às demandas que os movimentos de bairros traziam ao cenário político da cidade. Atento, percebeu o quanto do sucesso do PCB se devia a seu engajamento nessas questões, compreendeu a importância dos CDPs e intuiu o potencial eleitoral das SABs.

Com seu estilo peculiar, Jânio manipulava muito bem os símbolos e temas que o identificavam com a população dos bairros suburbanos. Foi, possivelmente, o primeiro político a levar questões como luz elétrica, transporte, moradia, escola, creche, saneamento básico, calçamento etc. (enfim, a agenda dos CDPs e das SABs e) para dentro Legislativo municipal. Em seus discursos na tribuna da Câmara, protestava contra muitos dos problemas vividos cotidianamente pelos trabalhadores da capital e, ao fazê-lo, legitimava as demandas oriundas dos subúrbios. A carestia, os abusos cometidos por comerciantes inescrupulosos, a falta de moradia e transportes, os atrasos dos trens, eram, entre outros temas, constante e veementemente retomados pelo vereador Jânio Quadros.

A falta de serviços públicos nos bairros operários era apresentada não como resultado da natureza ou como conseqüência de um crescimento urbano desordenado, inevitável e acelerado. Esses problemas eram tratados como conseqüência do descaso da administração pública, e sua solução era apresentada como um direito do morador, não como um benefício resultante de uma dádiva. Os discursos do vereador Jânio Quadros davam vida a sentimentos profundamente introjetados no imaginário popular: é dever do Estado cuidar do bem-estar dos cidadãos. Mais que isso, seus discursos anunciavam os instrumentos privilegiados para a conquista desses direitos:

[...] não devem nada ao poder público [os moradores do bairro], porque essas ruas são conservadas pela Sociedade Amigos do Jardim da Saúde, que até caçamba própria possui e, sobretudo, o pedregulho; adquire a pedra, adquire os tijolos quebrados e procede aos consertos que se fazem necessários [...] estive in loco, não uma vez, mas duas, a pé, correndo as ruas ponta a ponta e conversando com a população. A Sociedade dos Amigos do Bairro cedeu um prédio para a instalação de um posto policial, construiu celas, deu cadeia, dois lotes para a construção da escola [...]. A Sociedade dos Amigos da Saúde, cujo nome não me canso de repetir, devo repetir necessariamente, porque ela éo poder público de lá”. (Anais da Câmara Municipal, 4/10/1948, grifo meu) 
Assim, foi transformando as SABs e sua agenda em plataforma político-eleitoral que Jânio Quadros consolidou sua carreira política. Suas visitas aos bairros, além de articular uma série de vínculos e apoios nas associações locais, permitiam o contato direto com um grande número de trabalhadores pouco acostumados a ver políticos por perto, sobretudo fora dos períodos eleitorais. Nesses contatos, Jânio foi construindo a imagem de um político diferente: homem simples e acessível, próximo e interessado na vida e nos problemas dos pobres. E, com uma aguda percepção das questões sociais relacionadas às demandas dos bairros periféricos, Jânio se transformou no seu porta-voz.

As disputas entre Ademar e Jânio nessa "bolsa de trocas e favores" revelam que não havia uma relação inquebrantável de fidelidade entre os moradores dos bairros periféricos e os políticos. Entrevistas com antigos membros dos CDPs e das SABs mostram que foi muito freqüente o trânsito da adesão entre um e outro. A eficácia das lealdades estava assentada na troca do voto pelo atendimento das reivindicações dos bairros. Talvez resida aí a marca desse "clientelismo" urbano que se experimentava no pós-guerra. Na verdade, o que parecia estar em disputa era a representação popular: que voz se constituiria na expressão da sua vontade? Nessa disputa, havia muitos candidatos: os comunistas e os CDPs; Ademar e o PSP; Jânio Quadros; as SABs, além da UDN, PTB, PSD e outros partidos menores (Duarte, 2002).

\section{Concluindo}

Diante da capilaridade e da pujança dos CDPs e das SABs duas perguntas são inevitáveis: qual a validade de se utilizar a noção de clientelismo para explicar as relações entre os políticos e os movimentos de bairro nos anos 1940 e 50 ? Por que essas sofisticadas organizações populares que encenaram, entre as décadas de 1940 e 60, as duras batalhas pelo direito de falar e de agir e pelas melhorias urbanas não foram designadas pelas investigações acadêmicas como movimentos sociais, quando esse tema alcançou a universidade nas décadas de 1970 e 80 ?

Clientelismo é um conceito relacional, mas implica supor que a ação política está apenas em um dos pólos da relação: do lado dos políticos que concedem os favores e que outorgam os benefícios; do outro lado, existiria apenas uma massa amorfa, de receptores passivos e inconscientes, que apenas receberia os favores e os benefícios e por isso seria presa fácil da lógica do favor. Entretanto, a trajetória dos CDPs e das SABs nos mostra um conjunto de ações políticas muito bem planejadas e calculadas, muito distante da passividade e impossível de ser classificado como inconsciente, por qualquer ângulo que se tome esse adjetivo. $\mathrm{Na}$ trajetória do associativismo de bairro, nem sempre é fácil dizer quem usa quem: os políticos e os partidos usam as associações de bairro ou o contrário? 
Então começamos a entrar em contato com os políticos para melhorar o clube financeiramente... Depois nós arrumamos uma sede. Eu entrei em contato com todos os partidos, mas eu tinha mais contato com o pessoal do Ademar, compreende! [...] Aí pensamos que precisávamos de um campo de futebol, para arrumar o campo precisávamos de um terreno, para depois falar com o vereador para ver se ele quebrava um galho para passar um trator e tudo mais [...] aí o vereador mandou passar o trator [...] o candidato vinha até a sede do clube distribuía santinho, fazia comício [...] nós pegávamos as coisas, mas votávamos nos outros... Enchia [de gente] viu! Porque quando chegavam as eleições [...] arrumava aparelho de som e tudo [...] então eu trazia as pessoas pra ver o candidato, tudo isso, né. Então, quando chegava a eleição o pessoal dizia: 'Seu João quem é seu candidato?', né! (Entrevista com o pedreiro comunista João Louzada, 6/11/1998).

O conceito de clientelismo sugere um estado de apatia e letargia que não existiu no associativismo de bairro do pós-guerra. Ao nos referirmos a ele como se fosse capaz de descrever a realidade, o que se perde são as especificidades que o conflito de classe pode assumir em cada caso concreto, e os arranjos e as negociações políticas que dão forma a esses conflitos. Além disso, o conceito de clientelismo está umbilicalmente ligado à idéia do atraso das classes populares, atraso na sua consciência de classe, atraso na sua organização sindical, atraso na sua organização partidária. Enfim, ele expressaria um descompasso na sua própria constituição enquanto classe, o que faria com que ela aparecesse na esfera pública apenas como massa. Entretanto, "as massas são sempre os outros, aqueles que não conhecemos e que não podemos conhecer [portanto] não há massas, apenas maneiras de ver os outros como massas" (Williams, 1969: 309).

Afinal, por que os CDPs e as SABs não foram problematizados como movimentos sociais? Aqui é possível supor que, mais uma vez, o "problema do populismo", principalmente adjetivando uma época, a da "República populista", parece ter obstruído nossa percepção sobre esses movimentos sociais das décadas de 1940 e 50. A questão que parece decisiva é que, quando o tema dos movimentos sociais se tornou importante objeto de estudo, no fim dos anos 1970, foi saudado como portador de uma novidade: a autonomia em face dos partidos políticos e do Estado. Entretanto, os movimentos sociais de bairro, entre 1945 e 1964, não pareciam caber nesse figurino. Afinal, como vimos, naquele contexto, autonomia não significava manter-se imune às influências partidárias ou do Estado, e sim transitar por elas sem se perder em apenas uma, aproveitando, com um forte senso de oportunidade, todos os estímulos e as possibilidades abertas, 
independentemente da sua orientação ideológica. A idéia de autonomia como independência dos partidos e do Estado não parece ter tido muita relevância para os movimentos sociais nas décadas de 1940 e 50. Naquele momento, o que importava era conquistar os serviços urbanos que colocassem os pobres também como beneficiários do desenvolvimento econômico, os tornassem parte da cidade e lhes dessem "um lugar no mundo". Não importava de onde viria o benefício, e por isso todos os canais (políticos, partidos, sindicatos etc.) eram acionados, dando a esses movimentos uma enorme capacidade de adaptação.

Por muito tempo se acreditou que, por conta dessa grande plasticidade, as organizações populares seriam limitadas na sua ação, dependentes do Estado e submetidas aos interesses de políticos carismáticos. Assim, elas somente adquiririam visibilidade e existência sob a lógica do populismo. Uma síntese das opiniões sobre a diferença entre os novos os e antigos movimentos sociais sugeriu que:

a diferenciação básica não é entre os novos movimentos sociais (questões como gênero, raça, sexo, ecológicos etc.) e antigos (movimento operário clássico), como na Europa; a diferença é entre novos (lutas pela moradia e equipamentos coletivos em geral) e antigos movimentos populares (tipo sociedades amigos de bairros), onde imperavam práticas de cunho populista e clientelista. Observa-se que a diferenciação básica se dá na forma de fazer política, porque as articulações sempre existiram, tanto nos antigos como nos novos. Relações com a igreja, partidos e sindicatos sempre existiram, mas nos movimentos contemporâneos a relação é de outra natureza. As práticas e os repertórios também se alteraram. (Gohn, 2000)

Mais do que compreender o novo, parece fundamental aqui a necessidade de distingui-lo do antigo. Diante da suposta autonomia e pujança dos novos movimentos sociais, enfatizava-se a adesão às práticas clientelistas e a submissão aos líderes carismáticos dos antigos movimentos sociais; práticas que teriam contribuído, de forma decisiva, para as limitações estruturais da "República populista" e para seu desfecho na ditadura militar. Ao que parece, o momento em que se consolidou essa interpretação sobre os movimentos de bairro das décadas de 1940 e 50 foi marcado teórica e politicamente pela rejeição a tudo o que parecesse ter contribuído para o desenlace no golpe militar de 1964. E o associativismo de bairro, preso à "lógica populista" e "clientelista", emergia como parte do colapso da democracia nos anos 1960 e da falência da "República populista". 
Entretanto, em meados dos anos 1980 já se evidenciavam os limites da suposta autonomia dos chamados "novos movimentos sociais". As organizações que emergiram na década de 1970, sob a égide da "autonomia" e do "espontaneísmo", já encenavam um acentuado refluxo, em que se percebia uma clara tendência à sua institucionalização, fosse numa convergência para o Estado, fosse numa subsunção aos reestruturados partidos políticos, depois da abertura. Isso se deu, em parte, pela sua própria dinâmica interna, e em parte pela transformação do contexto político: "cria-se uma nova relação entre os movimentos e os partidos políticos, por um lado, e as agências públicas em geral, por outro. Começa a haver um fenômeno que foi muitas vezes chamado de cooptação" (Cardoso, 1994).

Ou seja, os novos movimentos sociais estavam ficando cada vez mais parecidos com os antigos. Essa inflexão produziu, no fim da década, o desabafo de Eder Sader, ao reconhecer que o projeto político implícito nos "novos" movimentos sociais sofrera uma derrota. Sader sugeria que os novos movimentos foram portadores de promessas inovadoras no cenário político nacional; as interpretações acadêmicas, contudo, premidas pelas necessidades imediatas da política, haviam se iludido quanto ao seu potencial (Sader, 1988).

No entanto, a superação dessa "ilusão" não produziu estudos empíricos acerca dos movimentos sociais das décadas de 1940 e 50 e, muito menos, tentativas de mapear as continuidades e as heranças de uma tradição associativa popular de mais de meio século. A conseqüência continua sendo a submersão das experiências e práticas políticas e sociais do associativismo popular no caldeirão desqualificador da "República populista", onde elas se mantêm, com raras exceções, mergulhadas. Nesse sentido, a política continua engolindo a História.

Notas

1. O Hoje teve início com uma tiragem diária de 20 mil exemplares, reduzida posteriormente para $10 \mathrm{mil}$.

Sobre as possibilidades e os riscos da utilização de jornais como fonte historiográfica, ver Capelato e Prado (1980) e Capelato (1989).

2. Todos os eleitos, conforme se lê em seus prontuários nos arquivos do Dops, tiveram atuação destacada nos CDPs e na formação subseqüente das

SABs. Do total de eleitores da Mooca nesse ano, os candidatos ligados aos CDPs tiveram $1 / 4$ do total de votos do bairro. Tribunal Regional Eleitoral, caixa 3247.

3. Em Vila Monumento circulou um panfleto semelhante: "Ao exemplo 
do que se está processando em todos os bairros desta capital [...] para reivindicações de melhorias e outras necessidades mais imediatas e mais sentidas do bairro. Para procurar facilitar ao povo os meios mais rápidos para proporcionar-lhe cultura [...] sem distinção de classe, nacionalidade, credo religioso ou facção política, comparecer à sede do Esporte Clube Vila Monumento...” Arquivos do Dops, Dossiê 20-Z-56.

4. Em entrevista com o operário têxtil e membro do diretório da UDN da Mooca, João Bezerra dos Santos, perguntei se ele nunca tinha feito parte de uma Sociedade de Amigos de Bairro. Ele respondeu: "Não, nunca fiz, porque isso era uma ramificação dos comunistas!” Entrevista com João Bezerra dos Santos, concedida ao autor em 12 de junho de 2000.

5. O Dops identificou Armando Pastrelli, residente à rua Venda Nova $\mathrm{n}^{\circ} 22$, como um "dos organizadores da Sociedade Amigos da $4^{\mathrm{a}}$ Parada e Belém da qual foi o $1^{\circ}$ secretário. Essa e outras sociedades, apesar de seus títulos não terem expressão política, sofrem forte infiltração comunista, segundo orientação do partido..."

Juntamente com Pastrelli foram indiciados Benedito Joffre, também eleito vereador, e Orlando Piazzoto, eleito deputado estadual. Arquivos do Dops, Prontuário n ${ }^{\circ}$ 83.293.

6. “[...] em regra os trabalhadores estiveram ausentes da vida política, ao nível das reivindicações urbanas [...] não foi hábito dos sindicatos [...] inscrever em seus programas questões ligadas à problemática urbana [...] [e] não se pode afirmar que as sociedades amigos de bairro sejam representativas dos trabalhadores. Elas representam muito mais o morador, uma categoria social que a cidade criou e cuja ação, na fase de metropolização de São Paulo, atenua, senão dissolve o comportamento de classe [de modo que] a maioria dos habitantes de São Paulo manteve-se politicamente à margem da vida municipal" (Cardoso, 1973: 12-13, grifo meu).

7. O investigador termina:

"Os oradores foram unânimes nos seus pontos de vista, baseados nos princípios de defesa do congelamento de preços e contra a carestia, deram vazão de suas iras, seus rancores contra os dirigentes do país". Arquivos do Dops, Prontuário 12.8079.

8. O ofício foi assinado pelo presidente da Federação, Sebastião Costa. Um mês depois o mesmo Sebastião Costa apareceu como representante do prefeito Ademar de Barros num comício promovido pela Liga Social de Vila Brasilândia. Arquivos do Dops, Dossiê 50-J-138-193 e 187. Para uma boa discussão da "greve dos 400 mil”, ver Fontes (1999)

9. Sobre a relação específica de Ademar e Jânio com os movimentos de bairro, e como isso explica o fenômeno do populismo, ver Duarte e Fontes (2004).

10. "Todo pedido tinha que passar primeiro pelo partido. Se a pessoa não viesse recomendada pelo representante local do PSP, tinha que voltar, se vincular e só então poderia ser atendida. Cada secretário de Estado tinha um elemento do partido que fazia o atendimento dos pedidos políticos [...]. Cada melhoria que o Ademar fazia, como governador, era favorável ao partido. Por exemplo, na criação de um posto de saúde, todos os funcionários eram nomeados pelo PSP". Depoimento de Edward Tesoto, 14/7/1977 em Sampaio (1982:137) 
ALEM, Sílvio. 1981. Os trabalhadores e a redemocratização: 1942-1948. Campinas, Unicamp, tese de doutoramento.

BADARÓ, Marcelo. 1988. Novose velhos sindicalismos. Rio de Faneiro, 1955-1988. Rio de Janeiro: Vício de Leitura.

BENEVIDES, Maria Victória de Mesquita. 1989. O PTB e o trabalhismo: partido e sindicato em São Paulo (1945-1964). São Paulo:

Brasiliense/Cedec.

CAPELATO, Maria Helena. 1989. Os arautos do liberalismo: imprensa paulista 1920-1945. São Paulo: Brasiliense. \& PRADO, Maria Lígia. 1980. O bravo matutino. Imprensa e ideologia: o jornal O Estado de S. Paulo. São Paulo: Alfa-Omega.

CARDOSO, Fernando Henrique (ed.). 1973. Cultura e participação na cidade de São Paulo. São Paulo: Cebrap.

CARDOSO, Ruth Corrêa Leite. 1994 A trajetória dos movimentos sociais. In: DAGNINO, Evelina (ed.). Anos 90: política e sociedade no Brasil. São Paulo: Brasiliense.

CASTANHA, Alfredo. Entrevista concedida ao autor em 6 de maio de 1999.

CASTELS, Manuel. 1980. Cidade, democracia e socialismo: a experiência das associações de vizinhança em Madrid. Rio de Janeiro: Paz e Terra.

COSTA Hélio da. 1995. Em busca da memória: comissão de fábrica, partido e sindicato no pós-guerra. São Paulo: Scritta.

DUARTE, Adriano Luiz. 2002. Cultura popular e cultura política no após-guerra: redemocratização, populismo e desenvolvimentismo no bairro da Mooca, 1942-1973. Campinas, Unicamp, tese de doutoramento.

\& FONTES, Paulo. 2004. O populismo visto da periferia: ademarismo e janismo nos bairros da Mooca e São Miguel Paulista, 1947-1953. Cadernos do AEL: populismo e trabalhismo, $\mathrm{vol}^{\circ} 11, \mathrm{n}^{\circ} 20 / 21$.

FONTES Paulo. 1999. Centenas de estopins acessos ao mesmo tempo: a greve dos 400 mil, piquetes e a organização dos trabalhadores em São Paulo - 1957. In: FORTES, Alexandre et al. Na luta por direitos: estudos recentes em História Social do Trabalho. Campinas: Ed. Unicamp. 2002. Comunidade operária, migração nordestina e lutas sociais: São Miguel Paulista, 1945-1966. Campinas, Unicamp, tese de doutoramento

FRENCH, John. 1988. Worker and the rise of adhemarista populism in São Paulo, Brazil, 1945-1947, The Hispanic American Historical Review $\mathrm{n}^{\circ} 68$.

1995. O ABC dos operários: conflitos e alianças de classe em São Paulo, 1900-1950. São Paulo: Hucitec/São Caetano do Sul: Prefeitura Municipal.

GERTEL, Noé. Entrevista concedida ao autor em 27 de agosto de 1999.

GOHN, Maria da Glória. 2000. Teoria dos movimentos sociais: paradigmas clássicos e contemporâneos. $2^{\mathrm{a}}$ ed. São Paulo: Loyola.

Jornal Hoje e Jornal Notícias do Hoje.

KOWARICK, Lúcio. 1988. As lutas sociais e a cidade. Rio de Janeiro: Paz e Terra. 
LOUZADA, João. Entrevista concedida ao autor em 6 de novembro de 1998.

MEKSENAS, Julius. Entrevista concedida ao autor em 15 de abril de 1999.

POMAR, Pedro. 1945. Os comunistas no movimento de massa. Informe ao Pleno da Vitória.

SADER, Eder. 1988. Quando novos personagens entram em cena: experiências e lutas dos trabalhadores da grande São Paulo, 1970-1980. Rio de Janeiro: Paz e Terra.

SAMPAIO, Regina. 1982. Ademar de Barros e o PSP. São Paulo: Global.
SANTOS, Wanderley Guilherme dos. 2006. Horizonte do desejo: instabilidade, fracasso coletivo e inércia social. Rio de Janeiro: FGV.

VINHAS, Moisés. 1982. O Partidão: a luta por um partido de massas 1922-1974. São Paulo: Hucitec.

WEFFORT, Francisco. 1980. O populismo na política brasileira. Rio de Janeiro: Paz e Terra.

WILLIAMS, Raymond. 1969. Cultura e sociedade. São Paulo: Companhia Editora Nacional.

\section{Resumo}

Este texto problematiza o surgimento dos Comitês Democráticos e Populares (CDPs) e das Sociedades de Amigos de Bairro (SABs), no final do Estado Novo, e procura compreender suas conexões com os novos partidos e as novas lideranças políticas surgidas no contexto do pós-guerra. Argumenta, também, que é por conta desses nexos que tais movimentos sociais foram desconsiderados, por muitas décadas, como objetos de estudo.

Palavras-chave: associativismo, cidadania, cultura política, movimentos sociais, trabalho

\section{Abstract}

The present article discusses how Democratic Popular Committees and Neighborhood Associations were created, by the end of the Estado Novo dictatorship, specially in the city of São Paulo, and tries to understand the connections between these organizations and the new political parties and leaders that appeared in the postwar years. It also suggests that it was because of these relations that such organizations were for a long time disregarded as a research topic.

Keywords: neighborhood associations, citizenship, political culture, social movements, labor 


\section{Résumé}

L'article discute comment ont été créés, à la fin de la dictature de l'Estado Novo, particulièremente dans la ville de São Paulo, les Comités

Démocratiques Populaires et les Associations d'Amis du Quartier, et essaie de comprendre les connexions entre ces organisations, les partis et les leaders politiques apparus dans les années d'après-guerre. On suggère que c'est à cause de ces rapports que ces organisations ont été négligées en tant qu'objet d'études.

Mots-clés: associations de quartier, citoyenneté, culture politique, mouvements sociaux, travail 